\title{
THE USE OF A GENERAL PRACTITIONER'S TIME
}

\author{
BY \\ D. L. CROMBIE AND K. W. CROSS \\ From the Department of Medical Statistics, University of Birmingham
}

In his presidential address to the Royal Statistical Society in 1951, Professor Bradford Hill gave details of a survey of the day's work of a doctor, based on records kept by doctors during the 12 months which ended July 1, 1939. The two main indices were attendances of patients at the doctor's surgery and visits by the doctor to insured patients, and variations were examined by day, week, and month. The same indices have also been used in surveys of the work of individual practitioners (McGregor, 1949; Pemberton, 1949; Fry, 1952). In an analysis of clinical records of eight practices, Logan (1953) measured morbidity by recourse to a consultation rate; Crawford (1954) in a survey of a practice in Northern Ireland conducted over a 2-year period used spell of illness.

These surveys provide no detailed knowledge of the use of a doctor's time, the subject considered in the present report. It is by no means easy to obtain information on this matter without undue interference with the routine of practice. The time spent with each patient is not normally recorded, and it is difficult to assess in respect of administrative and professional work not directly concerned with the care of patients.

\section{Material AND Methods}

The practice which is the basis of this study is in the charge of two partners. Its features are:

(a) location in a suburb of a large city;

(b) a high proportion of patients who are "blackcoated workers" or members of the higher income groups;

(c) a static population with a relatively high rate of inter-marriage;

(d) a relative absence of poor social conditions;

$(e)$ inclusion of two residential schools (the Birmingham Blue Coat School and a Home Office School) and a home for the Aged (St. Joseph's Home).

The inquiry, which is concerned only with patients treated by one partner (D.L.C.), began on April 14, 1953, and lasted 12 months; the Easter vacations in 1953 and 1954 were therefore excluded. Only National Health Service patients were considered, chiefly because there was no reliable list of private patients. There were 6,565 patients on the combined list of the two partners on April 1, 1953, and 6,690 patients on April 1, 1954 (excluding patients living at the residential schools and old people's home). The average number of patients at risk for the 12 months of the survey wes 6,628 .

At the time of this inquiry, figures obtainable from the Executive Council were known to be inflated by the inclusion of patients who had recently died or left the district, and it was not possible to contact every patient personally. Age and sex distribution of patients on the combined list was therefore estimated from a representative sample (the first 800 names in alphabetical order). Both partners recorded the number of episodes of illness treated and the number of patients in each of the age groups specified below. The number of patients in each age group for whom one partner (D.L.C.) was responsible was calculated by assuming that, in any particular age group, patients treated by each partner suffered the same number of episodes of illness in a given time. Except for a somewhat larger proportion, especially of females aged 65 years and over, the age distribution of patients is very similar to that of the populations of Birmingham and of England and Wales.

A punch-card was completed for each doctor-patient "contact"; a contact comprised either an attendance by the patient at the surgery or a home visit to the patient. The time spent on each "contact" was recorded, and the total time spent on all "contacts" with each patient was calculated at the end of each "episode".* The total number of surgery attendances and the total number of home visits which took place during each episode we also recorded. If a patient suffered from an illness in which periods of normal health were broken by recurring spells of ill-health, each new spell of illness was classed as a separate episode. Other items of information included the patient's age, sex, and marital state, the diagnosis, and the degree of severity of the illness.

In previous surveys of single practices, broad classifications of illness derived from the W.H.O. nomenclature of diseases have been used. The W.H.O. classification is, however, less suitable for use in general practice than in hospital, because the incidence of serious illness is relatively much lower, and an alternative method was employed which involved separate recording of the system most affected and the type of lesion.

"An "episode of illness" is taken as the basic unit of medical care and covers the period of ill-health from onset to conclusion. 
TABLE I

USE OF PRACTITIONER'S TIME (HOURS PER WEEK)

\begin{tabular}{|c|c|c|c|c|c|c|c|c|c|c|c|c|c|c|c|}
\hline \multirow{2}{*}{\multicolumn{3}{|c|}{$\frac{\text { Year }}{\text { Month }}$}} & \multicolumn{9}{|c|}{1953} & \multicolumn{3}{|c|}{1954} & \multirow{2}{*}{$\begin{array}{l}\text { Aver- } \\
\text { age }\end{array}$} \\
\hline & & & April* & May & June & July & Aug. & Sept. & Oct. & Nov. & Dec. & Jan. & Feb. & March & \\
\hline \multirow{3}{*}{$\begin{array}{l}\text { Time } \\
\text { Spent }\end{array}$} & \multirow{2}{*}{$\begin{array}{c}\text { In } \\
\text { Contact } \\
\text { with } \\
\text { Patients }\end{array}$} & $\begin{array}{c}\text { At } \\
\text { Surgery }\end{array}$ & $14 \cdot 0$ & $13 \cdot 1$ & $12 \cdot 8$ & $11 \cdot 6$ & $7 \cdot 0$ & $13 \cdot 2$ & $14 \cdot 0$ & $15 \cdot 0$ & $13 \cdot 0$ & $15 \cdot 3$ & $15 \cdot 2$ & $16 \cdot 9$ & $13 \cdot 4$ \\
\hline & & $\begin{array}{c}\text { At } \\
\text { Patients' } \\
\text { Homes }\end{array}$ & $6 \cdot 6$ & $5 \cdot 8$ & $7 \cdot 4$ & $4 \cdot 9$ & $5 \cdot 0$ & $8 \cdot 1$ & $9 \cdot 1$ & $7 \cdot 0$ & $5 \cdot 4$ & $7 \cdot 4$ & $8 \cdot 0$ & $8 \cdot 5$ & $6 \cdot 9$ \\
\hline & Travellin & $\cdots$ & $5 \cdot 4$ & $5 \cdot 4$ & $4 \cdot 2$ & $3 \cdot 9$ & $2 \cdot 9$ & $3 \cdot 8$ & $5 \cdot 5$ & $5 \cdot 2$ & $5 \cdot 2$ & $6 \cdot 0$ & $7 \cdot 3$ & $6 \cdot 4$ & $5 \cdot 1$ \\
\hline \multicolumn{2}{|c|}{ Total Time } & $\cdots$ & $26 \cdot 0$ & $24 \cdot 3$ & $24 \cdot 4$ & $20 \cdot 4$ & $14 \cdot 9$ & $25 \cdot 1$ & $28 \cdot 6$ & $27 \cdot 2$ & $23 \cdot 6$ & $28 \cdot 7$ & $30 \cdot 5$ & $31 \cdot 8$ & $25 \cdot 4$ \\
\hline
\end{tabular}

* Figures for this month refer to two weeks in April, 1953, and two in April, 1954.

TABLE II

TIME SPENT (MIN.) IN CONTACT WITH PATIENTS DURING ONE YEAR

\begin{tabular}{|c|c|c|c|c|c|c|c|c|c|c|c|c|c|c|}
\hline $\operatorname{Sex} \quad \ldots \quad \ldots$ & & & & Male & & & & & & & Female & & & \\
\hline Age Group (yrs) & $\underset{\mathbf{5}}{\text { Under }}$ & $5-14$ & $15-29$ & $30-44$ & $45-64$ & $\begin{array}{c}65 \text { and } \\
\text { over }\end{array}$ & $\begin{array}{l}\text { All Age } \\
\text { Groups }\end{array}$ & $\underset{5}{\text { Under }}$ & $5-14$ & $15-29$ & $30-44$ & $45-64$ & $\begin{array}{c}65 \text { and } \\
\text { over }\end{array}$ & $\begin{array}{l}\text { All Age } \\
\text { Groups }\end{array}$ \\
\hline Total Time (min) & 3,771 & 3,602 & 4,167 & 5,791 & 6,362 & 5,567 & 29,260 & 3,263 & 3,909 & 6,052 & 7,980 & 8,059 & 4,926 & 34,189 \\
\hline $\begin{array}{l}\text { Number of } \\
\text { Patients on List } \\
\text { Mean Time per } \\
\text { Patient on List }\end{array}$ & $\begin{array}{r}195 \\
19 \cdot 3\end{array}$ & $\begin{array}{r}328 \\
11 \cdot 0\end{array}$ & $\begin{array}{r}356 \\
11 \cdot 7\end{array}$ & $\begin{array}{r}462 \\
12 \cdot 5\end{array}$ & $\begin{array}{r}375 \\
17 \cdot 0\end{array}$ & $\begin{array}{r}182 \\
30 \cdot 6\end{array}$ & $\begin{array}{r}1,898 \\
15 \cdot 4\end{array}$ & $\begin{array}{r}170 \\
19 \cdot 2\end{array}$ & $\begin{array}{r}267 \\
14 \cdot 6\end{array}$ & $\begin{array}{r}446 \\
13 \cdot 6\end{array}$ & $\begin{array}{r}500 \\
16 \cdot 0\end{array}$ & $\begin{array}{r}550 \\
14 \cdot 7\end{array}$ & $\begin{array}{r}368 \\
13 \cdot 4\end{array}$ & $\begin{array}{r}2,301 \\
14 \cdot 9\end{array}$ \\
\hline $\begin{array}{l}\text { Number of } \\
\text { Patients Seen* } \\
\text { Mean Time per } \\
\text { Patient Seen.. }\end{array}$ & $\begin{array}{r}179 \\
21 \cdot 1\end{array}$ & $\begin{array}{r}236 \\
15 \cdot 3\end{array}$ & $\begin{array}{r}242 \\
17 \cdot 2\end{array}$ & $\begin{array}{r}315 \\
18 \cdot 4\end{array}$ & $\begin{array}{r}272 \\
23 \cdot 4\end{array}$ & $\begin{array}{r}147 \\
37 \cdot 9\end{array}$ & $\begin{array}{r}1,391 \\
21 \cdot 0\end{array}$ & $\begin{array}{r}159 \\
20 \cdot 5\end{array}$ & $\begin{array}{r}228 \\
17 \cdot 1\end{array}$ & $\begin{array}{r}307 \\
19 \cdot 7\end{array}$ & $\begin{array}{r}360 \\
22 \cdot 2\end{array}$ & $\begin{array}{r}344 \\
23 \cdot 4\end{array}$ & $\begin{array}{r}182 \\
27 \cdot 1\end{array}$ & $1,580 \frac{\mathrm{C}}{21 \cdot 6}$ \\
\hline $\begin{array}{l}\text { Number of } \\
\text { Episodes } \\
\text { Mean Number of } \\
\text { Episodes per } \\
\text { Patient on List } \\
\text { Mean Time per } \\
\text { Episode } \quad \text {. }\end{array}$ & $\begin{array}{l}393 \\
2 \cdot 0 \\
9 \cdot 6\end{array}$ & $\begin{array}{l}439 \\
1 \cdot 3 \\
8 \cdot 2\end{array}$ & $\begin{array}{r}384 \\
1 \cdot 1 \\
10 \cdot 8\end{array}$ & $\begin{array}{r}499 \\
1 \cdot 1 \\
11 \cdot 6\end{array}$ & $\begin{array}{r}461 \\
1 \cdot 2 \\
13 \cdot 8\end{array}$ & $\begin{array}{r}268 \\
1 \cdot 5 \\
20 \cdot 8\end{array}$ & $\begin{array}{r}2,444 \\
1 \cdot 3 \\
12 \cdot 0\end{array}$ & $\begin{array}{l}2 \cdot 0 \\
9 \cdot 5\end{array}$ & $\begin{array}{l}448 \\
1 \cdot 7 \\
8 \cdot 7\end{array}$ & $\begin{array}{r}559 \\
1 \cdot 3 \\
10 \cdot 8\end{array}$ & $\begin{array}{r}680 \\
1 \cdot 4 \\
11 \cdot 7\end{array}$ & $\begin{array}{r}617 \\
1 \cdot 2 \\
13 \cdot 1\end{array}$ & $\begin{array}{r}316 \\
0.9 \\
15 \cdot 6\end{array}$ & $\begin{array}{r}2,962 \\
1 \cdot 3 \\
11 \cdot 5\end{array}$ \\
\hline
\end{tabular}

* Patients seen more than once are entered only once

\section{RESULTS}

Use of the General Practitioner's Time.-A practitioner's activities may be considered under three headings:

(i) contact with patients;

(ii) travelling between patients;

(iii) administration.

The last includes consolidating visits and commitments, assembling dressings and other equipment, making entries on N.H.S. record cards, telephoning and dealing with correspondence, discussing mutual professional problems with partner, and referring to past records or literature. A record was kept of the time spent on these duties each week for the first 6 months of 1952, and the mean time over the period was found to be 5 hours per week. This estimate excludes the time spent by the practitioner waiting for patients or consultants at the surgery or while on call at home. Although weekly values varied about this mean (from 2 to 7 hours), there was little variation from month to month. When the demand for patient care was heavy during a particular week, the time spent on administrative duties was reduced for that week, but was increased in the subsequent week. The time spent travelling between each visit to a patient was recorded on each day over several weeks; the mean travelling time per visit was 5.2 minutes. This figure was used to estimate the travelling time in a given period.

Monthly variations in respect of time spent in contact with patients and in travelling are shown in Table I. In calculating mean values only bankholidays have been excluded. In all months, excluding February and March, less than 30 hours per week were spent in actual contact with patients and in travelling between them. As would be expected, August had a very low value, and the values for May and December were low compared with those for adjacent months even after allowance had 
been made for bank-holidays. The maximum values for time spent on visits and in travelling between patients' homes occurred for the months in the first quarter of 1954 and in October 1953.

Over the year, the practitioner spent slightly more than 30 hours per week on all activities subsumed under the three headings specified above ( 20 hours per week during August and about 35 hours per week during the first 3 months of 1954).

From this point the discussion is concerned with a detailed consideration of time spent in contact with patients. It should be mentioned that the travelling time was greatest at the extremes of life, because of the relative inability of very young and very old patients to attend the surgery.

Time Spent according to Age and Sex of Patients. - Table II relates time spent during the year to the number of patients at risk, the number of patients seen, and the number of episodes of illness. The mean time per episode is a measure of the seriousness of the illness, and the mean number of episodes per patient is a measure of the prevalence of illnesses seen by the practitioner.

Most children under 5 years of age were seen at some time during the year, and, in relation to the number of patients, experienced more episodes of illness than any other age-group, but the time per episode was relatively short. The time spent per patient was greatest for males aged 65 and over and lowest for females aged 65 and over. The mean time per patient seen was greatest for both sexes in this age-group.

Crawford (1954) and Pinsent (personal communication) also found that the number of spells of illness per male patient increased at late ages, whereas female rates showed little change or declined. Similar results were obtained in the present inquiry for St. Joseph's Home for the Aged.

Time SPEnT according to Nature of Illness.It has previously been mentioned that illnesses have been classified jointly by system most affected and type of lesion. In Table III, only those systems and types of lesion are shown which contributed more than 1 per cent. to the total number of episodes, regardless of sex. The Table shows the proportionate contribution of various diagnostic categories to the total time. Infective and inflammatory lesions of the respiratory system, and ear, nose and throat accounted for more than one-fifth of the practitioner's time. The relatively high proportion attributable to infections of skin and connective tissue were due largely to an epidemic of impetigo. Infective and inflammatory lesions of all systems combined accounted for more than one-third of the total time. Degenerative lesions of the cardiovascular system and psychogenic disorders of the nervous system contributed more than 5 per cent. to the total time spent in contact with patients.

We now consider time spent in relation to the number of episodes of illness (Table III). Although the mean time spent on male episodes was almost identical with that spent on female episodes, there were several sex differences among individual diagnostic groups. The care of a male episode referable to the cardio-vascular system took half as much time again as did the care of a female episode, and there was an even greater difference between the sexes for degenerative lesions of this system (a contributory factor to the sex differences in time spent

TABLE III

USE OF TIME DURING ONE YEAR ACCORDING TO TYPE OF ILLNESS

\begin{tabular}{|c|c|c|c|c|c|}
\hline & & & Total Time & $\begin{array}{l}\text { Mean } \\
\text { Episod }\end{array}$ & $\begin{array}{l}\text { ne per } \\
\text { (min.) }\end{array}$ \\
\hline Diagunotic & $\mathrm{m}_{\mathrm{B}}$ & & (per cent.) & Male & Female \\
\hline $\begin{array}{l}\text { Respiratory } \\
\text { Infective and Ir } \\
\text { Other }\end{array}$ & $\ddot{\min }$ & & $\begin{array}{r}16 \cdot 3 \\
11 \cdot 7 \\
4 \cdot 6\end{array}$ & $\begin{array}{l}13 \cdot 8 \\
11 \cdot 3 \\
28 \cdot 1\end{array}$ & $\begin{array}{r}11 \cdot 6 \\
9 \cdot 8 \\
24 \cdot 1\end{array}$ \\
\hline $\begin{array}{c}\text { Skeletal } \\
\text { Traumatic } \\
\text { Degenerative } \\
\text { Other } \quad \cdots\end{array}$ & $\begin{array}{l}\cdots \\
\cdots \\
\cdots\end{array}$ & $\begin{array}{l}\ddot{ } \\
\ddot{*} \\
\cdots\end{array}$ & $\begin{array}{l}8 \cdot 2 \\
3 \cdot 6 \\
1 \cdot 3 \\
3 \cdot 3\end{array}$ & $\begin{array}{r}9 \cdot 0 \\
8 \cdot 2 \\
11 \cdot 6 \\
9 \cdot 8\end{array}$ & $\begin{array}{r}9 \cdot 8 \\
7 \cdot 6 \\
7 \cdot 9 \\
13 \cdot 9\end{array}$ \\
\hline $\begin{array}{c}\text { Cardio-Vascular } \\
\text { Degenerative } \\
\text { Other } \quad \cdots\end{array}$ & $\begin{array}{l}\cdots \\
\cdots\end{array}$ & $\begin{array}{l}\cdots \\
\cdots \\
\cdots\end{array}$ & $\begin{array}{l}7 \cdot 0 \\
5 \cdot 8 \\
1 \cdot 2\end{array}$ & $\begin{array}{r}33 \cdot 5 \\
40 \cdot 3 \\
17 \cdot 0\end{array}$ & $\begin{array}{l}21 \cdot 0 \\
23 \cdot 6 \\
14 \cdot 5\end{array}$ \\
\hline $\begin{array}{c}\text { Nervous } \\
\text { Degenerative } \\
\text { Psychogenic } \\
\text { Other }\end{array}$ & $\begin{array}{l}\cdots \\
\ddot{*} \\
\dot{*}\end{array}$ & $\begin{array}{l}\cdots \\
\cdots \\
\cdots\end{array}$ & $\begin{array}{r}11 \cdot 6 \\
2 \cdot 3 \\
5 \cdot 9 \\
3 \cdot 4\end{array}$ & $\begin{array}{l}14 \cdot 3 \\
15 \cdot 7 \\
14 \cdot 0 \\
13 \cdot 7\end{array}$ & $\begin{array}{r}10 \cdot 4 \\
7 \cdot 2 \\
11 \cdot 2 \\
11 \cdot 0\end{array}$ \\
\hline $\begin{array}{l}\text { Genito-Urinary } \\
\text { Infective and In } \\
\text { Metabolic and } \\
\text { Other }\end{array}$ & $\begin{array}{l}\text { amn } \\
\text { atrit } \\
\cdots\end{array}$ & & $\begin{array}{r}10 \cdot 2 \\
1 \cdot 9 \\
5 \cdot 1 \\
3 \cdot 2\end{array}$ & $\begin{array}{c}25 \cdot 0 \\
(22 \cdot 0)^{*} \\
26 \cdot \overline{5}\end{array}$ & $\begin{array}{l}25 \cdot 0 \\
17 \cdot 3 \\
33 \cdot 7 \\
17 \cdot 9\end{array}$ \\
\hline $\begin{array}{l}\text { Gastro-Intestinal } \\
\text { Infective and In } \\
\text { Degenerative } \\
\text { Psychogenic } \\
\text { Other } \quad .\end{array}$ & $\begin{array}{l}\ddot{m} \\
\cdots \\
\cdots\end{array}$ & $\begin{array}{l}\ddot{y} \\
\cdots \\
\cdots \\
\cdots\end{array}$ & $\begin{array}{r}12 \cdot 8 \\
4 \cdot 3 \\
3 \cdot 4 \\
0 \cdot 9 \\
4 \cdot 2\end{array}$ & $\begin{array}{r}15 \cdot 1 \\
9 \cdot 9 \\
24 \cdot 5 \\
9 \cdot 2 \\
16 \cdot 8\end{array}$ & $\begin{array}{r}12 \cdot 4 \\
11 \cdot 6 \\
19 \cdot 9 \\
7 \cdot 0 \\
14 \cdot 3\end{array}$ \\
\hline $\begin{array}{l}\text { Ear, Nose and Th } \\
\text { Infective and In } \\
\text { Metabolic and } \\
\text { Other }\end{array}$ & $\begin{array}{l}\text { at } \\
\text { imm } \\
\text { atrit } \\
\cdots\end{array}$ & & $\begin{array}{r}11 \cdot 4 \\
9 \cdot 1 \\
0 \cdot 9 \\
1 \cdot 4\end{array}$ & $\begin{array}{r}8 \cdot 6 \\
8 \cdot 2 \\
5 \cdot 7 \\
18 \cdot 8\end{array}$ & $\begin{array}{l}7 \cdot 5 \\
7 \cdot 5 \\
6 \cdot 3 \\
8 \cdot 3\end{array}$ \\
\hline $\begin{array}{l}\text { Skin and Connect } \\
\text { Traumatic } \\
\text { Infective and In } \\
\text { Allergic } \quad . \\
\text { Other } \quad \cdots\end{array}$ & $\begin{array}{l}\mathrm{Ti} \\
\ddot{\mathrm{mm}} \\
\ddot{\cdots}\end{array}$ & $\begin{array}{c}\mathrm{es} \\
\ddot{\mathrm{ry}} \\
\ddot{*} \\
\cdots\end{array}$ & $\begin{array}{r}13 \cdot 2 \\
1 \cdot 8 \\
5 \cdot 5 \\
1 \cdot 9 \\
4 \cdot 0\end{array}$ & $\begin{array}{r}8 \cdot 2 \\
7 \cdot 1 \\
7 \cdot 4 \\
8 \cdot 7 \\
10 \cdot 7\end{array}$ & $\begin{array}{r}8 \cdot 5 \\
8 \cdot 8 \\
7 \cdot 1 \\
7 \cdot 8 \\
11 \cdot 8\end{array}$ \\
\hline $\begin{array}{l}\text { Whole Body . } \\
\text { Infective and In } \\
\text { Metabolic and } \\
\text { Other }\end{array}$ & $\cdots$ & $\begin{array}{l}\cdots \\
\text { al } \\
\cdots\end{array}$ & $\begin{array}{l}6 \cdot 3 \\
2 \cdot 1 \\
1 \cdot 0 \\
3 \cdot 2\end{array}$ & $\begin{array}{l}10 \cdot 1 \\
10 \cdot 2 \\
(8 \cdot 5)^{*} \\
13 \cdot 1\end{array}$ & $\begin{array}{r}9 \cdot 7 \\
8 \cdot 4 \\
9 \cdot 7 \\
10 \cdot 7\end{array}$ \\
\hline Other Systems & .. & .. & $3 \cdot 0$ & $10 \cdot 3$ & $20 \cdot 0$ \\
\hline All Categories & $\cdots$ & $\cdots$ & $\begin{array}{r}100 \cdot 0 \\
(63,449)\end{array}$ & $12 \cdot 0$ & $11 \cdot 5$ \\
\hline
\end{tabular}

- Figures in brackets are based on less than twenty episodes 
on patients aged 65 years and over). Degenerative lesions of the gastro-intestinal system and of the nervous system also gave rise to sex differences; the higher male values were mainly due to larger numbers of male patients with peptic ulceration and with serious illnesses of the nervous system. High values for lesions of the respiratory system, other than infective and inflammatory, are explained by the inclusion of a small number of patients with neoplasms. This is also true of the genito-urinary and gastro-intestinal systems. The highest mean time spent on female episodes was referable to pregnancy and its complications.

\section{SUMmary}

1. An examination has been made of the time spent by a general practitioner during a 12 month period in the care of 4,200 National Health Service patients.

2. Slightly more than $\mathbf{3 0}$ hours per week were spent in contact with patients, on travelling between them, and on administration. Monthly values ranged from 20 hours per week during August (1953) to 35 hours per week during February and March (1954).

3. Time spent in contact with patients has been related to the number of patients at risk, number of patients seen, and number of episodes of illness. Rates are given by sex and age group; those referable to male patients aged 65 years and over were outstandingly high.

4. The proportionate contribution of various diagnostic categories to the total time is shown. Infective and inflammatory conditions accounted for more than one-third. In relation to the number of episodes of illness, there were several sex differences among diagnostic groups.

\section{REFERENCES}

Crawford, J. C. C. (1954). British Journal of Preventive and Social Medicine, 8, 81 .

Fry, J. (1952). Brit. med. J., 2, 249

Logan, W. P. D. (1953). "General Practitioners' Records". Studies on Medical and Population Subjects No. 7. General Register Office. H.M. S .

McGregor, R. M. (1950). Edin. med. J., 57, 433.

Pemberton, J. (1949). Brit. med. J., 1, 306.

Pinsent, R. J. F. H. (1954). Personal communication. 